Tetiana Krotova, Kalyna Pashkevych. Dialogics of folk tradition and author's interpretation...

DOI https://doi.org/10.30525/978-9934-26-065-0-9

Tetiana Krotova, Doctor of Arts, Professor, Professor of the Department of Artistic Designing of Costume, Kyiv National University of Technologies and Design, Kyiv, Ukraine ORCID 0000-0001-6367-0317

Kalyna Pashkevych, Doctor of Technical Sciences, Professor, Professor of the Department of Ergonomics and Design, Kyiv National University of Technologies and Design, Kyiv, Ukraine ORCID 0000-0001-6760-3728

\title{
DIALOGICS OF FOLK TRADITION AND AUTHOR'S INTERPRETATION IN MODERN WEDDING FASHION
}

\begin{abstract}
The purpose of the paper. To analyze artistic and compositional solutions in modern women's wedding clothes, to present the development of models of wedding clothes by means of mixed techniques based on the interpretation of its established forms in combination with traditional ornamental motifs of Poltava region. The methodology of the study. The analysis of scientific sources is based on literary-analytical and comparative methods; for analysis of visual sources and materials methods of observation, visual-analytical, as well as formal, figurative and stylistic analysis were used. The authors also applied systemstructural analysis, transformation, interpretation and image-associative methods when using ornamental motifs in the process of modeling women's wedding clothes. The scientific novelty consists in defining the possibilities of applying the traditional art of embroidery and painting of fabrics in combination with the author's interpretation of women's wedding clothes. Practical significance consists in the application of the combination of embroidery and ornamentation elements of Poltava region and modern fashion trends in the process of formation and manufacture of modern wedding clothes. The conclusions. The art of embroidery and painting fabrics is an important means of decorating clothes, and young women are ready to experiment with the cut, placement of ornaments, and a combination of different decoration techniques in creating wedding clothes. Modern fashion trends, materials, a variety of textures give designers the opportunity to reinterpret the wedding
\end{abstract}


dress, while using elements of traditional decoration. The authors offer models of wedding clothes, which combine the idea of transformation of the established form and cut with elements of the traditional trimming made by means of the mixed techniques. In this way the dialogue of folk traditions and modern interpretation of wedding fashion is actualized.

Keywords: wedding fashion, folk traditions, interpretation, ornament of Poltava region.

\section{INTRODUCTION}

In Ukraine, embroidery and painting of clothes have long been the most common and affordable forms of folk art. They are a manifestation of the decorative reproduction of images of the world, nature, human feelings, people's historical background. There are a large number of ethnographic centers of embroidery Kyiv, Chernihiv, Poltava, Podil, Pokut, Hutsul, Bukovyna and other regions. Each of the embroidery centers differs from the other by its unique features.

Ornamental compositions applied to elements of clothing by means of embroidery and painting are distinctive and have a symbolic content. People have long believed that self-made protection amulets can protect against evil forces and bring luck. The ornament on clothes, towels, tablecloths gives the product uniqueness and is used for creation of a refined wedding dress. For many centuries, the dialogic nature of folk art has expanded the boundaries of local cultural traditions, enriching all areas of modern life, including wedding fashion. Thus, the relevance of the research topic is due to the growing interest in the national cultural heritage and the need to find design methods that allow to actualize the dialogue of traditional art and the author's interpretation of the wedding costume.

\section{LITERATURE REVIEW}

The dialogic nature of decorative and applied art and modern author's interpretations in costume modeling can be traced both in the scientific literature and in the practical activities of designers and masters. In order to harmoniously combine traditional motifs with modern forms and silhouettes, it is necessary to turn to works that reveal the characteristics of different types of decorative and applied arts, folk costumes, embroidery, and ornaments. We would like to single out among such publications the works by R. Zakharchuk-Chugai and M. Stankevych [1], M. Bilan and G. Stelmashchuk [3], 
Tetiana Krotova, Kalyna Pashkevych. Dialogics of folk tradition and author's interpretation...

T. Kara-Vasylieva [14], V. Kostyukova [19], Z. Vasina [5], etc. Examining the national costumes, M. Bilan and G. Stelmashchuk note: "An in-depth study of folk costumes hands us the famous magic ball from fairy tales, which leads to the infallible path of resurrection of memory. Traveling after it, we learn how our distant ancestors lived and worked, how they gained and accumulated experience, how they dressed up on weekdays and holidays, how they looked individually and all together in a group, whom they respected and despised" $[3,6]$.

Unique samples of traditional clothing provide a variety of interesting material for creating individual models of clothing and collections in ethno-style, decorated with artistic embroidery. M. Kolosnichenko and K. Pashkevych [16], N. Chuprina [30], T.V. Nikolaeva, T. Shafranska, T.I. Nikolaeva [23], O. Kolosnichenko, M. Norets, I. Frolov, I. Gayova [17], T. Krotova [20], M. Melnyk [22] emphasize the value of folk costume as a creative source in their works; features of the use of artistic painting and new decorating techniques in clothing and footwear collections were studied by G. Shchutska, O. Patlashenko, T. Bezsmertna [31] and others. Thus, M. Kolosnichenko and K. Pashkevych note: "Traditional Ukrainian costume has been formed over the centuries and has been constantly changed depending on the territorial affiliation ... The simplicity of the cut of the Ukrainian folk costume was favorable for the development of patterned artistic weaving, as well as for the ornamentation of clothing with embroidery and various decorations. Ornamentation reflects the ethnic history, local features of a particular costume. Each element of the ornament of the Ukrainian costume played a certain symbolic role. Clothing design was determined by the purpose of clothing, age and wealth of the owner. The features of the costume that distinguished it from others were the fabric, its color, location, color and type of ornament, as well as the belt, headdress, shoes, removable jewelry, etc." [16, 5-6].

Creative solutions for the use of folk motifs in modern clothing are extremely diverse. That is why the main fashion trends are constantly expanding. Modern fashion for wedding dresses has become more flexible; it can combine and mix different styles and trends - from Gothic and Baroque to the avantgarde in various manifestations of eclecticism. As is argued by N. Chuprina and M. Kolosnichenko, "... at the present stage of the fashion system operation and the creation of fashion trends, eclecticism is used increasingly. ... The dress inspired by eclecticism has a harmonious look, it is made in a certain figurative 
key, but at the same time does not fit classical canons and rules [30, 99-100]. So, there are no standard solutions in fashion, and the outfit depends entirely on the taste, mood and imagination of the consumer and fashion designer.

Creating an outfit for the most important event in life took a prominent place in the history of costume. Thus, Egyptian women wore kalaziris for weddings a garment sewn from two rectangular cloths, with one or two wide straps complemented it with jewelry. In ancient Greece, the bride's outfit was peplos, which consisted of a piece of long cloth and two fasteners. The more noble the bride's family was, the more luxurious such fasteners were. The bride's head was covered with a yellow cape (prototype of a veil), which symbolized the sun and happiness [4, 7-19].

In ancient Rome, the bride wore a fiery veil on her head, and the outfit itself consisted of two tunics with long sleeves and a high neckline. The first mention of the dress, which was made and worn at the wedding, refers to the medieval fashion of the XV century - these are "cotardie" and "blio" dresses, which were complemented by a short white headdress [4, 69-75].

The most common colors for a wedding dress of the Baroque period (XVII century) were gold, yellow and coral; characteristic features of this outfit were a narrow waist, wide neckline, lush sleeves and abundant decoration with ribbons, pearls, lace, flowers. A characteristic feature of the wedding dress of the Rococo era is a lush skirt-paneer, a narrowed corset and a train, the length of which determined the status of the bride [28, 145-173].

It was not until XIX that the first white wedding outfits appeared. On February 10, 1840, an event took place at the Chapel of St James's Palace in London, marking a momentous era of change. It started with the Queen's dress. The Queen ignored a traditional monarch's heavy brocade wedding dress, decorated with precious stones and half-closed with a velvet cape with ermine fur. The bride's dress turned out to be both royally precious and girlishly modest and chaste. ... In the XIX century the white color embodied luxury and wealth, joy and prosperity, as opposed to innocence and pure love. ... Queen Victoria's wedding changed everything so much that by the 1880s most brides wore white or ivory dresses. It was to be expected that brides would follow Her Majesty's choice of dress. The British tradition supports white in women's dresses, as can be seen in the images of Lady Diana Spencer in 1981 and Kate Middleton in 2011 [25]. 
Tetiana Krotova, Kalyna Pashkevych. Dialogics of folk tradition and author's interpretation...

However, where fashion is not subject to strict etiquette requirements, designers make new creative models. In 1995, Claudia Schiffer closed the show of the couture collection Valentino in a wedding dress made of silk and organza [13]. An example of innovative design can be seen in Fernando Claro during ATELIER COUTURE fashion week on March 29, 2017 at the Fernand Nunez Palace in Madrid [25].

The analysis of designers' works representing models of wedding dresses showed that each of them has their own vision of the image of the bride: someone combines classic forms with a modern cut, someone adds the character of historicism to the image. However, everyone strives for one thing: to emphasize the uniqueness of the moment with the help of the most exquisite fabrics and trimmings in accordance with modern fashion trends.

\section{RESULTS AND DISCUSSION}

\section{Ethnic style in wedding fashion}

The development of Ukrainian fashion in the late XX - early XXI centuries was marked by the intensification of ethnic tendencies. "Creatively rethinking folk costume, the designer, first of all, reveals the following features: the symbolic function of the costume and its figurative solution; ways of forming folk clothes; materials; rationality and aesthetics of independent elements of the "folk costume" system (headdress, shoes, accessories, etc.); decorative solution of the costume (embroidery, applied ornament, fringe, ribbon, etc.); way of wearing different elements of the national costume; fabrication method" [33, 117].

Clothing modeling in Ukraine has been significantly influenced by ethnicity in recent decades. It is being spread due to the need to meet the natural need of people for a variety of clothes. We can highlight the following main features of this style:

- wide use of natural fabrics, fabrics with components of the weaving patterns imitating manual national weaving;

- multilayers of clothing;

- simple cut;

- application of decor in the form of artistic embroidery on the sleeves, at the bottom of the skirt;

- trimming with ribbons, fabrics of contrasting colors;

- $\quad$ use of printed fabrics with folklore elements. 
Ethno-style clothing is especially popular in the spring and summer, when the wardrobe provides opportunities for experiments with color and style. Exquisite dresses, blouses, sundresses, suits, trousers, shirts, jackets - there are no restrictions for the implementation of national cultural trends. Ukrainian ethno-style is associated with embroidery, and the technique of decorating products went beyond the usual loose linen shirt with long sleeves. In the modern world, the embroidered shirt (vyshyvanka) has undergone various modifications.

Having analyzed fashion trends, we can say that embroidered dresses and suits are in great demand. These can be long dresses with straight, slimline, semi-fitted silhouettes for active everyday wear in the city, trousers and overalls, a modern interpretation of Ukrainian folk-style embroidered shirts, a dress-shirt or safari model and many others. Minimalist models, especially from unbleached canvas, look original with accessories in ethnic or boho style, bright dresses decorated with embroidery, on the contrary, require minimalist monochromatic details. "Referring to traditions, fashion offers only a new look at their essence and functions. In the fashion context, ethnicity becomes interesting to society not only as part of the national traditional culture, but also as an instrument of existence in the present, as a special configuration of human-time relations," argues M. Melnyk [22].

Among Ukrainian designers who create models of wedding dresses in ethnostyle, we can single out Oksana Polonets - her brand has received recognition and development not only in Ukraine but also far beyond its borders - in 2015 the fashion shows took place in Chicago and New York [11;29]. O. Polonets' collections are always endowed with symbolic significance; its main task is to convey the originality of Ukrainian art and sophistication. In 2008, the designer created her first collection of wedding and evening dresses in the national style. She presented an exquisite collection of wedding dresses in the capital of Malaysia, Kuala Lumpur on August 27, 2019 at the invitation of the Embassy of Ukraine (Fig. 1).

The invited guests, among whom were members of the royal family, were impressed by the beauty and elegance of Ukrainian designer clothes [25]. In the presented collection, the author successfully combined ancient ornaments with modern trends in shaping forms. As you can see, O. Polonets skillfully stylizes elements of the national costume, ornaments, emphasizing that traditional motif can be a stylish, refined decor for wedding clothes. 
Tetiana Krotova, Kalyna Pashkevych. Dialogics of folk tradition and author's interpretation...

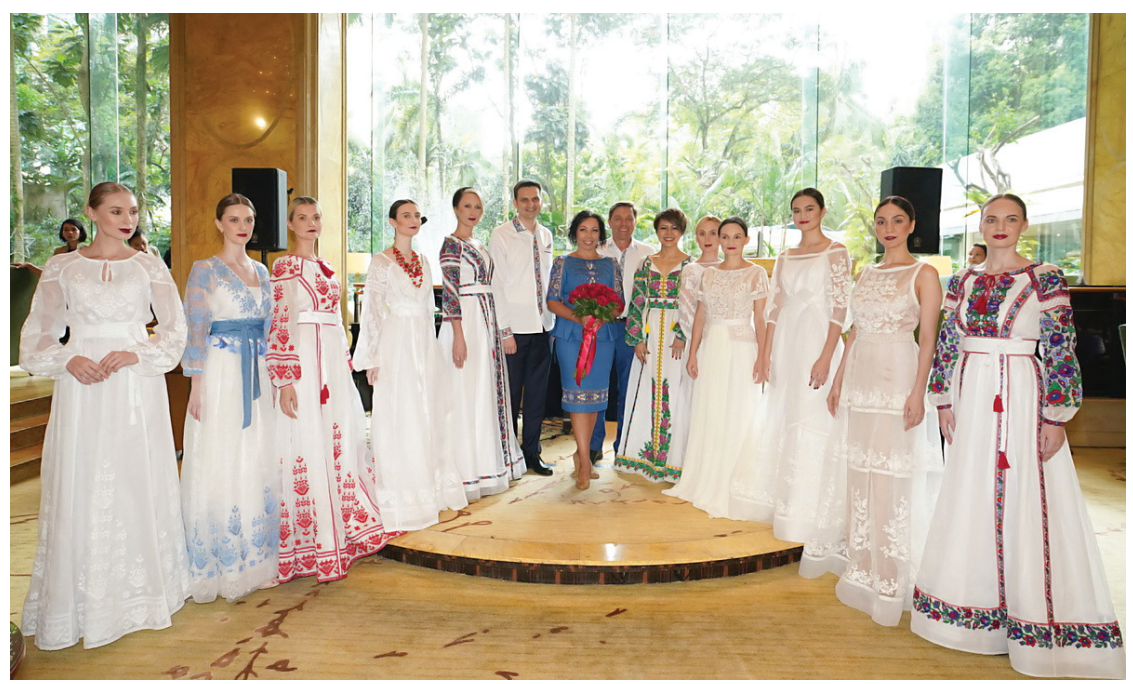

Fig. 1. Oksana Polonets after the presentation of the collection of wedding dresses in the capital of Malaysia, Kuala Lumpur. August 27, 2019

Women's and men's dress is presented by the "Siniy Lyon" (Blue Flax) Ukrainian manufacturer (Fig. 2) [32]. It is made in white, red and black colors, in machine embroidery techniques, and will be an expressive option for those grooms and brides who prefer clothing sets in a single artistic and stylistic solution.

Among the masters and designers who pay attention to wedding attire in their work, few are those who revive the authentic techniques of weaving and hand embroidery. Among them is the name of Lviv master Daria Pryimak. "My clients are mostly intelligent young people," says the master. These are people who appreciate art, know their traditions, are interested in folk art; want to be original and different from everyone. There are many artists, singers and actors among them. I am very happy that young people are interested in my work. After all, this means that Ukrainian traditions are not forgotten, they are remembered and respected. For my part, I do my best so that they do not get disappointed and fall even more in love with our culture" [18]. Woven clothing, presented in Fig. 3, 


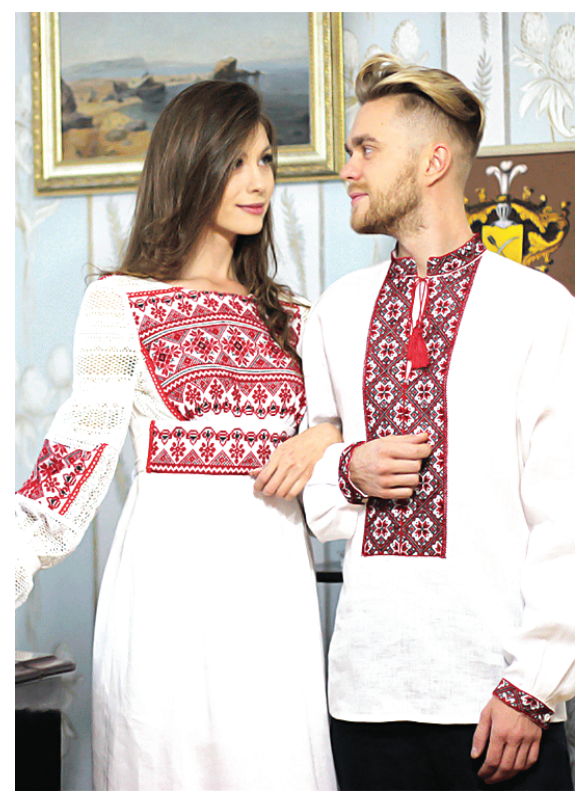

Fig. 2. Wedding dress. Manufacturer: Blue Flax Company, 2020

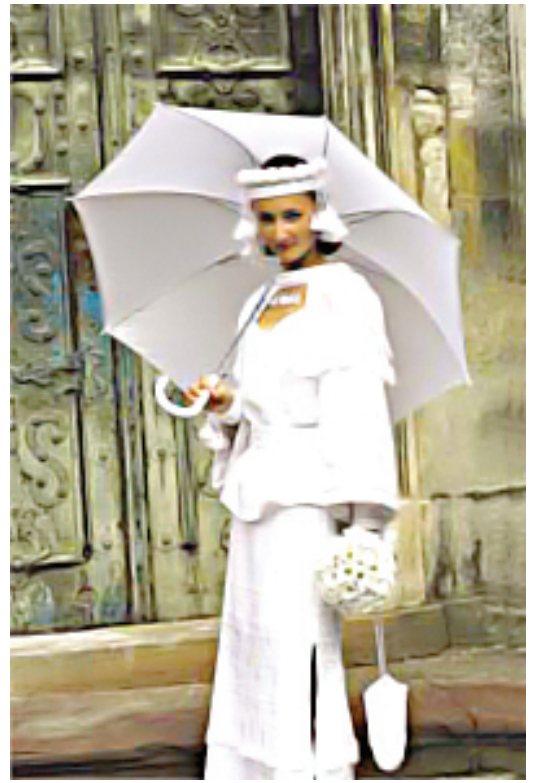

Fig. 3. Daria Priymak. Wedding dress. Lviv, 2009

consists of a blouse with wide sleeves and a belt and a long skirt. "... You can even weave a masterpiece out of an ordinary cotton thread. I often use silk, acrylic, lurex, less often - flax. It is also important that the dress does not wrinkle, so I introduce special additions to the structure of the fabric" [18]. It takes D. Priymak about two months to make a dress, during which the bride has to come to the dress fitting 5-6 times. Thus, craftsmen of decorative art and designers note a great interest of young people in folk traditions, as well as in wedding dresses with elements of Ukrainian embroidery, weaving, and ornamentation.

2. Traditional costume and ornamentation of Poltava region as a source of modern wedding attire

The following cities and localities belong to Poltava region: Poltava, Karlivka, Gadyach, Kobeliaky, Lubny, Zinkiv, Reshetylivka, Kremenchuk, Myrhorod, 
Tetiana Krotova, Kalyna Pashkevych. Dialogics of folk tradition and author's interpretation...

Lokhvytsia, Khorol, Opishne, Sorochyntsi, Lyutenka. There are many wealthy Cossack villages and towns in these territories, in which the costumes of the inhabitants have influences of European fashion, for example, in the complicated composition of embroidery.

In women's clothing, all elements were made of home-woven materials, except for the spare, which is sewn from factory-colored fabric of oriental origin $[3,114]$. XIX century saw the beginning of embroidering the whole sleeve and the needlework was done in white. Thus, embroidery on the shirt was performed in the "white on white" technique, accompanied by trimming [2] (Fig. 4). Among all other regional styles, the Poltava style of embroidery is recognizable, first of all, by this technique and color. Blue, beige, gray and ocher threads were also widely used; less often Poltava craftswomen chose a red palette of shades. It is also the most complex technique of Ukrainian embroidery; it has more than 180 types. It is recognized as one of the most refined in the world. Embroidery is the most popular branch of folk art among the others in Poltava region. Embroidery is applied on clothes, towels, hats and outerwear.

Shirts were embroidered mainly with linen threads: unbleached, white or dyed. G. Stelmashchuk and M. Bilan write about the specific features of the bride's dress according to the traditions of Poltava region: "The bride's outfit is especially luxurious. It has a detachable linen shirt covered with embroidery of patterns, which showed the symbolism of the wedding ceremony and fertility, a woolen sheet, which always looked solemn, because it is completely covered with ornaments that stood out on a colorful background, woven with patterns spare, woolen or brocade $[3,123]$. "The bride's wedding shirt is a folk women's epic, written by young hands for many centuries. One cannot put it into words! One can only marvel and bow before each of its lines. Here is a powerful geometric ornament precisely laid on a white canvas with white threads. Chiselled embroidery, with shearing and cutting combined with hem-stich. Such embroidery is typical for the northern regions of Poltava region. Floral motifs and the tree of life done in red and black from the southern regions of Poltava region are no less impressive" $[3,128]$.

The young woman wore a red corset sewn from purchased fabric and decorated with an applique of cloth and velvet (northern districts of Poltava region), or a colorful calico tank top with pleats at the back (southern districts 
of Poltava region). In Poltava region, the jackets were luxuriously decorated with floral ornaments embroidered on the sleeves, shoulders, and bottom $[3,128]$.

The girl was girded with a long towel embroidered with the tree of life. The towel depicts the roots, trunk and branches of a tree, which symbolize the dead ancestors, as well as the present and future life of a young family (Fig. 5). A flowerpot with a flowering plant, birds and a flower is one of the strongest and most effective talismans in Ukrainian embroidery. The collection of Poltava wedding towels is stored in the Poltava Museum of Local Lore named after V. Krychevsky [26]. This symbol was a talisman, a sign of healing, purification from evil. It was embroidered in red threads, adding black. Red traditionally symbolizes the sun, as well as fire, which cleanses from evil forces. Thus, the decoration played a big role; the ornamentation reflected the ethnic history, the local features of a certain costume, where each element of the ornament played a symbolic role. It is the presence of a towel and a wreath that indicate that it is a wedding dress.

Much attention was paid to the bride's jewelry, because they symbolized the wealth of the family. The bride wore a series of corals with silver inserts,

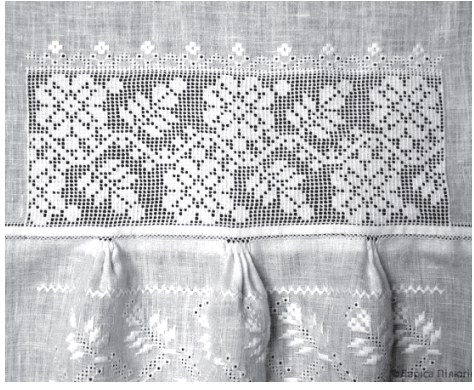

Fig. 4. Traditional Poltava "white on white" embroidery with shearing. L. Pilyugina. A fragment of a women's blouse, Reshetylivka village, Poltava region
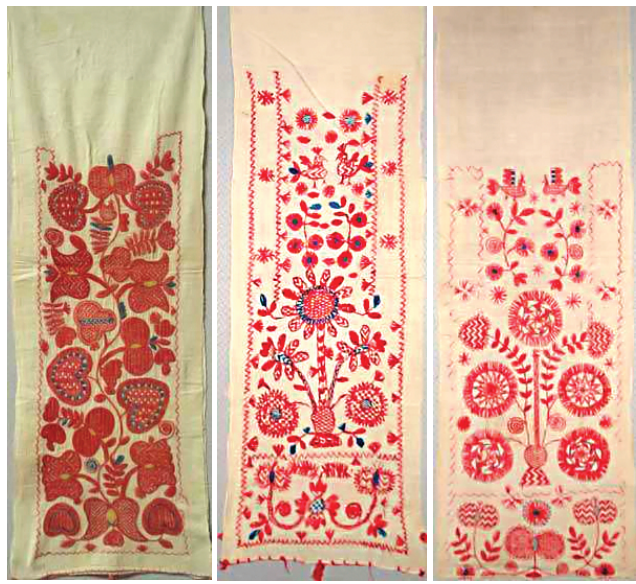

Fig. 5. Poltava wedding towels.

Poltava Museum of Local Lore named after V. Krychevsky 
Tetiana Krotova, Kalyna Pashkevych. Dialogics of folk tradition and author's interpretation...

necklaces made of Venetian glass, a dukach with a bow (Fig. 6). If the family did not have such jewelry, they borrowed it. Wedding hats were very diverse. In the northern districts of Poltava region, the bride's wedding scarf and a wreath laid on it were a sign-symbol for the bride. In the southern regions of Poltava region, the bride's head was decorated with a headtire made of green, blue, red ribbons, and a sizeable wreath made of artificial flowers, wool and paper, and in summer - even fresh flowers $[3,128]$. The girls braided their hair into two braids and laid it on their heads in the form of a wreath, adorned on top with gold laces, gold mesh or gold lace. They also wore one braid, weaving multicolored ribbons into it.

A unique worldview is embedded in the ornaments of the Poltava embroidery technique. Features of style of life, customs, household activities, housekeeping are read from geometric signs: triangles, rhombuses, crosses and other symbols. The skill is to write these signs in each other and be able to read these messages.

A characteristic feature of this region is the coexistence of geometric, floral, plant-geometric ornaments, which have preserved archaic, magical amulet motifs of crosses, anthropomorphic motifs depicting the "tree of life", sun, birds, 4, 6, 8-angular "stars", rhombuses. The force of tradition defeated the changing trends of the time, selected and preserved the ornaments that have reached the XXI century, and we need to study them and use them

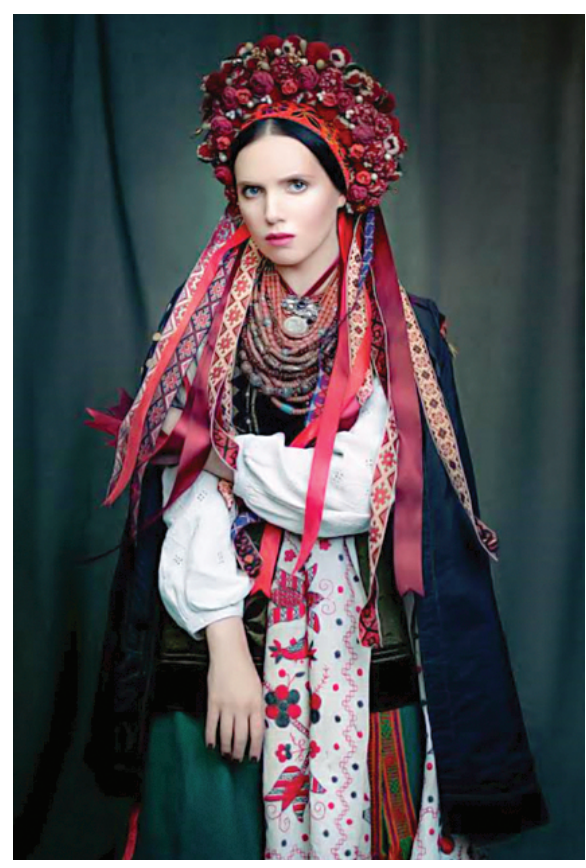

Fig. 6. Wedding costume from the private collection of Vladimir Shchybria. The wreath is made by Makoviya workshop, jewelry and dukach - from the private collection of Olena Bugaychenko 
in creating clothes for special events, because a person always needs a sense of protection.

In addition, the traditional embroidery of this region is marked by a large number of plant motifs (mallows, poppies, roses bloom abundantly on shirts and towels, which are considered magical talismans) and decoration with hem-stich, which give the embroidered products lightness and airiness. Our ancestors were well aware of the power of plants and transmitted their magic on canvas. When embroidering women's shirts, the masters first of all made sure that the sleeves looked the richest. So-called broken branches (horizontal), vertical broken trees and other similar elements are used for their decoration. Mandatory details are also the symbols of the sun and the earth as the main elements. During the work of the embroiderer, the patterns are lined with black or colored stripes. Among the methods of embroidery, masters love the "behind the needle" or "forward with a needle" stitch. The number of shirts, the quality of the fabric, its width, the richness of embroidery were a manifestation of the wealth of the owner.

\section{Interpretation of ornamental motifs by means of mixed method in} the artistic decoration of women's wedding clothes

The art of decorating fabrics in different ways has been known since ancient times. First, there was the weaving pattern, which was created by a special weave of threads in the process of making fabrics. Later, the drawing began to be applied by hand. Wooden printing boards were later invented. Decorating is an integral part of modern fashion. Currently many researchers devote their studies to the issue of decorating techniques [10;12; 27; 31]. It was believed that painting on fabric is a talisman for man, so in ancient times, this technique of decor has flourished. Artistic painting on fabric, leather or other materials is usually done by hand, thus creating a separate art form. Techniques of painting in most cases are related to the batik technique [31, 427].

Modern techniques of fabric painting are very diverse. Batik has absorbed the features and artistic methods of many techniques and types of fine arts watercolors, pastels, graphics, stained glass, mosaics. Significant simplification of painting techniques, compared to traditional techniques, and a variety of special tools allows you to paint various items of clothing, interior items, paintings, etc. Batik art gave a significant impetus to the improvement of decorative items and 
Tetiana Krotova, Kalyna Pashkevych. Dialogics of folk tradition and author's interpretation...

industrial fabrics. The creative work done in this technique, in one way or another, contributed to the enrichment of graphic and vivid language in the creation of the decor of industrial fabrics, and this, in turn, accelerated the emergence of new printing methods.

Various types of fabrics are used for painting - wool, viscose, silk and synthetic fabrics, each of which has its own characteristics for applying paint and requires the use of different dyes. The pattern on the clothes gives the image of uniqueness and can be used to create an elegant evening dress, bright summer dress, casual clothes, interesting and exclusive wedding dresses, as well as theatrical and carnival costumes, which includes much handwork.

\section{The concept and design phases of the wedding dress collections with ornamental motifs of Poltava region}

To create a future fashion line, modern fashion trends are analyzed. The questionnaire method was used to determine the preferences of the target segment. The first questionnaire is designed to identify the consumer segment, specify the image of a potential consumer, their age, field of activity, lifestyle and income level, as well as the attitude to the creative source. The second questionnaire aimed to explore the style preferences and compositional characteristics of clothes, which are preferred by a certain category of consumers.

Based on the results of the analysis, it is established that potential consumers are young women aged 21-26, who mostly combine work and study. Most of them are involved in the fashion industry, creative industries, show business. A significant number of respondents believe that Ukrainian ornaments should be used on festal dress. For most respondents, it is convenient to form a capsule wardrobe for the summer or spring period of the wedding celebration. The selection of clothes is based mainly on the criteria of compliance with fashion trends, as well as their own style and image, and convenience is also an important criterion. Interviewees are well informed and interested in learning more about the topic of creative source.

The analysis of the results of the second survey found that the vast majority choose X-shaped clothes and straight silhouettes, with full sleeves, straps, or sleeveless, with a waistline at the natural level or a high waistline; consumers also like the neckline, which emphasizes femininity. The most popular is a crewneck and a low neck (decollete). 
Many respondents prefer a long dress for the bride, or a short one with an attached train. The ratio of answers to questions about the color scheme is almost the same. Many young people believe that the fashion for a traditional white dress is no longer relevant, so you need to experiment with the color scheme of the dress and its length. A growing interest is observed in the use of trousers in the wedding costume.

The most popular are floral ornaments and a combination of floral and geometric motifs. It is worth noting that the respondents like to place the decoration not only on the usual areas of clothing (in the center of the front and on the sleeves), but also on the back and waist clothes. A significant number of respondents believe that ethno clothing is a current fashion trend, and the creation of a new modern outfit in this style expresses patriotism and love for their homeland.

To determine the signs-symbols of the collection, a system-structural analysis of the women's ensemble of Poltava region was carried out. The method of systemstructural analysis considers the object as a holistic system, so you can distinguish the main sign-symbol, proportions, main lines of division, rhythm and dynamics in the suit [8]. The method of the system-structural analysis made it possible to find out:

1) The sign-symbol of the costume: A-shaped;

2) Components of the basic shape: part of the bodice to the high waistline, inverted trapeze, lower part - A-shaped;

3) Division lines of the costume shape: neckline, armhole line, high waist line, corset end line, sheet end line, shirt high line;

4) Geometry of the supporting parts of the costume: shoulder belt shoulder line, sleeve end line;

5) Proportions of a costume: division into 4 parts - a head, a bodice, a skirt, legs;

6) Manifestations of static/dynamic, symmetrical shape of the costume: static and symmetrical shape;

7) Compositional center: the lower part of the costume is a skirt;

8) Rhythm and meter in the construction of the costume: rhythmic elements are located along the lines of the ornamental part of the apron and corset;

9) Rhythmic structure, proportional ratio: 1:1, 5:3,5. 
Morphological analysis is the basis for systematic thinking in the categories of basic structural features, principles and parameters; it helps to obtain many options for the ratio of lengths, silhouette shapes, cut and details of the suit. For the morphological analysis, we chose the clothing options that received the largest number of votes during the survey.

Based on the analysis of the ethnic trend in clothing and research, a collection of women's wedding clothing was developed, consisting of 3 blocks. The theme of the collection - "I breathe you" - reproduces the dialogue of traditions and modern trends, conveys the idea of combining past and future, points out to young people the importance of honoring their roots, understanding the meaning of ornament, culture and philosophy (Fig. 7-9). The collection was made at the Faculty of Design of the Kyiv National University of Technologies and Design by the master's degree student I. Ilyuk (scientific advisors: the research part K. Pashkevych, T. Krotova; design and composition - I. Davidenko).

The collection consists of blocks: a short dress; long dress; pants and overalls. The light color scheme reproduces the color of Poltava towels, where stylized
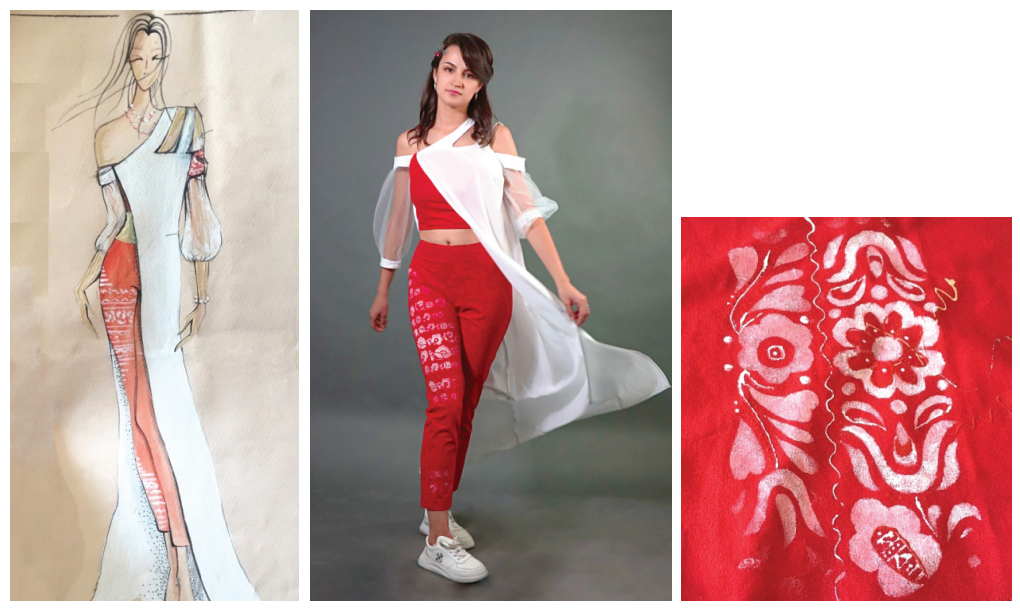

Fig. 7. Sketch of a model with trousers, a model made in the material, decorated with a painting based on Poltava ornament.

Photo by V.A. Sklyarenko 

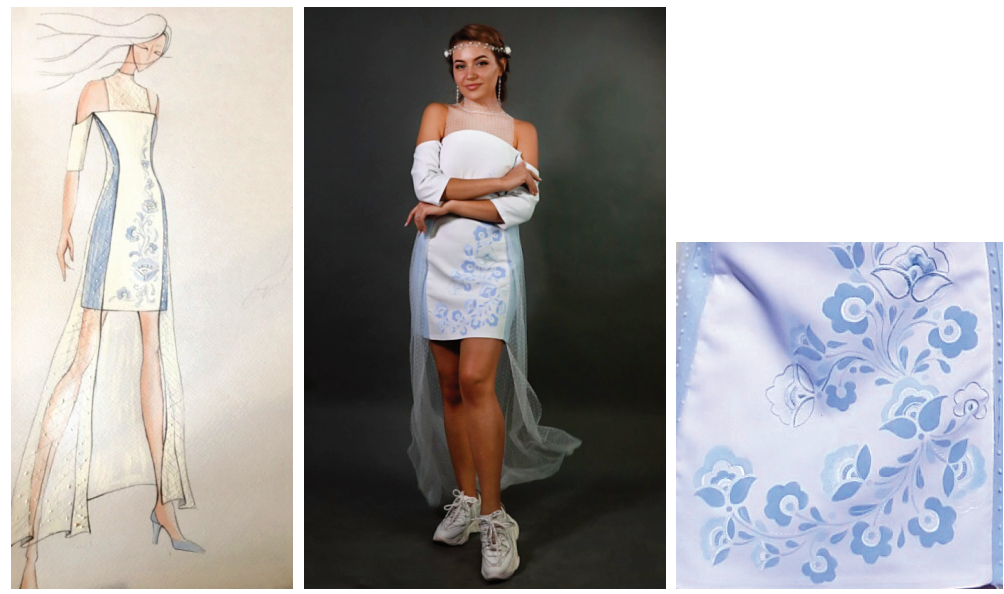

Fig. 8. Sketch of a model with a short dress, a model made in the material, decorated using mixed method: painting with textile paints and embroidery. Photo by V.A. Sklyarenko

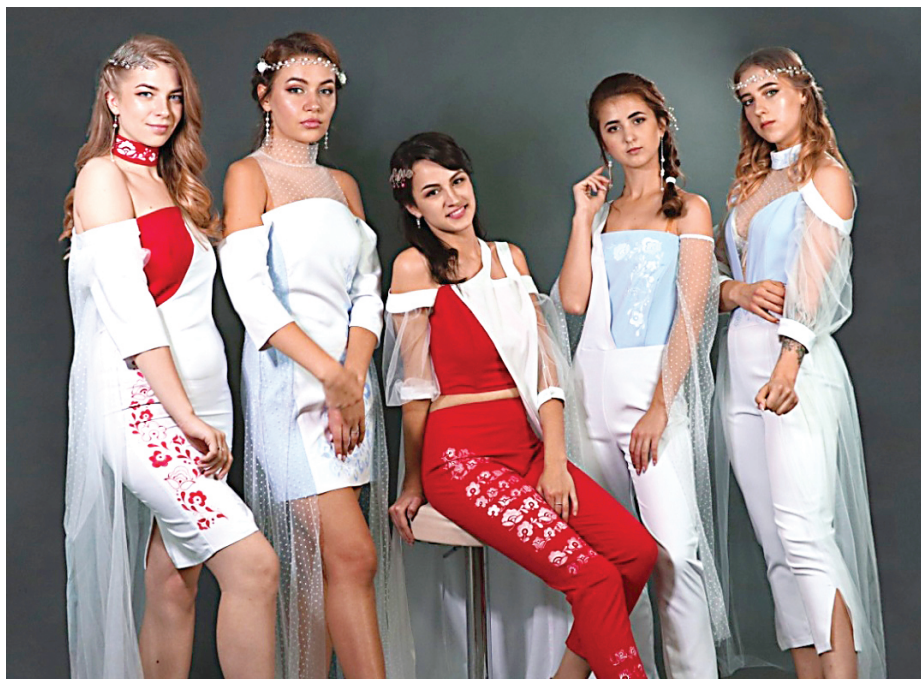

Fig. 9. Models of "I breathe you" collection. Photo by V.A. Sklyarenko 
Tetiana Krotova, Kalyna Pashkevych. Dialogics of folk tradition and author's interpretation...

elements of the composition "tree of life" are embroidered in red or blue on white. The main colors are white, blue and red. "Barbie" fabric and flock mesh were chosen for the production. Textile paints were used to decorate clothing elements with motifs of transformed ornaments, and mouline threads were used to embroider the contours of plant elements. Fig. 7, Fig. 8 show individual models of the collection "I breathe you."

\section{CONCLUSIONS}

The dialogic nature of traditions and modern author's interpretation occupies a prominent place in the fashion vein. The use of Ukrainian embroidery, ornaments and motifs of folk costumes provides a direct connection between generations and acts as a translator of the spiritual heritage of the Ukrainian people, because national traditional clothing is a unique phenomenon that reflects cultural heritage, depicts outlook, performs ritual and protective functions.

By analyzing the historical features and modern tendencies of wedding dresses, we can emphasize the predominance of manual work, multi-layering, combination of dense and light, translucent tissues. Among the distinctive features of ethno-style in modern clothes are the wide use of natural fabrics, fabrics with components of patterns imitating hand-made folk weaving; simplicity of the edges; use of decoration by means of artistic embroidery and painting; trimming of ribbons, fabrics of contrasting colors; use of printed fabrics with folklore elements.

To identify the patterns of tectonic structure of the costume, the authors carried out the definition of signs-symbols of the clothes collection of the Poltava region attire ensemble by the following stages: detection of the sign-symbol of the costume; breakdown of the form into constituent geometric elements; search for the supporting surface of the suit; main lines of division; proportional ratio of parts; metro-rhythmic organization of elements; detection of the degree of stasis and dynamism; determination of places of concentration of a decor in an outfit; identification of the compositional and psychological center of the costume. As a result, various combinations of forms and elements have been developed.

The models are made according to the author's creative design; the results of the research can be used for the design of collections of modern clothes of different purposes using folk motifs. 


\section{REFERENCES}

1. Antonovych Je. A., Zakharchuk-Chughaj R. V., Stankevych M. Je. (1993) Dekoratyvno-prykladne mystectvo [Arts and crafts]. Ljviv: Svit. (in Ukrainian).

2. Batyrjeva I. Tekhnologhija vykonannja vyshyvky «bilym po bilomu» selyshha Reshetylivka Reshetylivsjkogho rajonu Poltavsjkoji oblasti [Technology of white-on-white embroidery in the village of Reshetylivka, Reshetylivka district, Poltava region]. Available at: https://authenticukraine.com.ua/ blog/tehnologia-vikonanna-visivki-bilim-po-bilomu-dopracovanij (accessed 22 June 2021). (in Ukrainian).

3. Bilan M. S., Steljmashhuk Gh. Gh. (2011) Ukrajinsjkyj strij [Ukrainian attire]. Ljviv : Apriori. (in Ukrainian).

4. Blokhina I. V. (2007) Vsemirnaya istoriya kostyuma, mody i stilya [World history of costume, fashion and style]. Minsk : Kharvest. (in Russian).

5. Vasina Z. O. (2006) Ukrajinsjkyj litopys vbrannja : knygha-aljbom [Ukrainian chronicle of clothes: book-album]. T. 2 : XIII - pochatok XX st. : nauk.khudozh. Rekonstrukciji [XIII - early XX century: scientific and artistic reconstructions]. Kyjiv : Mystectvo. (in Ukrainian).

6. Vesiljni sukni v ukrajinsjkomu styli [Wedding dresses in the Ukrainian style]. Available at: https://allwed.biz/vesilni-sukni-v-ukrayinskomu-styli/ (accessed 3 June 2021). (in Ukrainian).

7. Vesiljne vbrannja. Vyrobnyk: kompanija «Synij ljon». 2020 [Wedding attire. Manufacturer: «Siniy Lyon», 2020]. Available at: https://sl-shop.com/vesilna-suknya-kvituche-pole.html (accessed 8 July 2021). (in Ukrainian).

8. Voskoboynikova A. E. (2013) Sistemnye issledovaniya: bazovye ponyatiya, printsipy i metodologiya [System studies: basic concepts, principles and methodology]. Znanie. Ponimanie. Umenie : inform. gumanit. portal [Informational and humanitarian portal "Knowledge. Understanding. Skill"]. no. 6. Available at: http://www.zpu-journal.ru/e-zpu/2013/6/Voskoboinikov_ Systems-Research/ (accessed 29 June 2021). (in Russian).

9. Darija Pryjmak vesiljnu suknju tche za misjacj [Daria Pryimak weaves a wedding dress in a month]. Available at: https:/gazeta.ua/articles/ hata-newspaper/_dariya-prijmak-vesilnu-suknyu-tche-za-misyac/153226 (accessed 23 July 2021). (in Ukrainian). 
Tetiana Krotova, Kalyna Pashkevych. Dialogics of folk tradition and author's interpretation...

10. Didukh A. (2015) Prosta aplikacija u kolekcijakh Pret-a-porte suchasnykh vitchyznjanykh dyzajneriv-modeljjeriv [Simple application in Prêt-à-Porter collections of modern domestic designers]. Visnyk Ljvivsjkoji akademiji mystectv, vol. 15, pp. 169-180. (in Ukrainian).

11. Dyzajn-studija Oksany Polonecj [Design-studio of Oksana Polonets]. Available at: https://polonets.prom.ua/p197416355-suknya-vesilna.html (accessed 3 July 2021). (in Ukrainian).

12. Istorija dekoratyvnogho mystectva Ukrajiny (2007) [History of decorative art of Ukraine] : in 5 vol. Vol. 2 : Mystectvo XVII-XVIII stolittja [Art of the XVII-XVIII centuries]. I NAN Ukrajiny, In-t mystectvoznavstva, foljklorystyky ta etnologhiji im. M. T. Ryljsjkogho. Kyjiv. (in Ukrainian).

13. Istoriya Valentino v 10 znamenitykh platyakh [Valentino's story in 10 famous dresses]. Available at: https://bazaar.ru/fashion/geroi/istoriya-valentino-v10-znamenityh-platyah-ot-anity-ekberg-do-dzheki-onassis/ (accessed 19 July 2021). (in Russian).

14. Kara-Vasyljjeva T. V. (2008) Istorija ukrajinsjkoji vyshyvky [History of the Ukrainian Embroidery] : kn.-aljbom. Kyjiv : Mystectvo. (in Ukrainian).

15. Kozlova T. V. (1975) Osnovy khudozhestvennogo proektirovaniya izdeliy iz kozhi [Fundamentals of artistic design of leather goods]. Moskva : Legkaya industriya. (in Russian).

16. Kolosnichenko M. V., Pashkevych K. L. (2018) Moda i odjagh. Osnovy proektuvannja ta vyrobnyctva odjaghu. Fashion and clothing. Fundamentals of clothing design and production : navch. posib. Kyjiv: KNUTD. (in Ukrainian).

17. Kolosnichenko O. V., Norecj M. V., Frolov I. V., Ghajova I. L. (2018) Zastosuvannja pryncypiv gharmonizaciji elementiv ukrajinsjkogho nacionaljnogho kostjuma $\mathrm{v}$ procesi proektuvannja suchasnogho odjaghu [Application of the principles of harmonization of elements of the Ukrainian national costume in the process of designing modern clothes]. Art and Design, no. 1, pp. 75-82. DOI: 10.30857/2617-0272.2018.1.7

18. Komar M. Interv'ju z vidomoju ljvivsjkoju dyzajnerkoju Darijeju Pryjmak [Interview with the famous Lviv designer Daria Pryimak]. Available at: https:// paramoloda.ua/glamur-iz-natsionalnymy-shvamy-abo-yak-viddatysya-odneodnomu-po-ukrayinsky (accessed 3 June 2021). (in Ukrainian).

19. Kostjukova V. M. (2019) Ukrajinsjkyj rushnyk - nevid'jemna skladova nacionaljnoji kuljtury [Ukrainian towel is an integral part of national culture]. 
Etnodyzajn u konteksti ukrajinsjkogho nacionaljnogho vidrodzhennja ta jevropejsjkoji integhraciji [Ethnodesign in the context of Ukrainian national revival and European integration] : zb. nauk. pr. / redkol.: gholov. red. M. I. Stepanenko, uporjad. i vidp. red. Je. A. Antonovych, V. P. Tytarenko ta in. Poltava: PNPU imeni V. Gh. Korolenka. Vol. 2, pp. 211-217. (in Ukrainian).

20. Krotova T. F. (2013) Etnomotyvy i klasychni formy v kostjumi: svoboda perevtilenj i mezhi stylju [Ethno motives and classical forms in a costume: freedom of reincarnations and limits of style]. Etnodyzajn: jevropejsjkyj vektor rozvytku i nacionaljnyj kontekst [Ethnodesign: European vector of development and national context] : mater. II Mizhnar. konghresu. Poltava, pp. 313-319. (in Ukrainian).

21. Lisovyj V. (1990) Dzherelo dukhovnogho zdorov'ja [The source of spiritual health]. Nauka i kuljtura. Ukrajina [Science and culture of Ukraine]. Kyjiv: Znannja. Vol. 24, pp. 576. (in Ukrainian).

22. Meljnyk M. T. (2008) Moda v konteksti khudozhnikh praktyk 20 stolittja [Ethnic direction of fashion design at the beginning of the XXI century] : (PhD Thesis) / Kyjivsjkyj nac. un-t kuljt. i myst. Kyjiv. Available at: https://www.researchgate.net/publication/332446738_Moda_v_konteksti_ hudoznih_praktik_HH_stolitta (accessed 3 August 2021). (in Ukrainian).

23. Moda lito-2019: fotoprynty, mikro-sumky ta kyshenjkovyj bum [Summer 2019 fashion: photo prints, micro-bags and pocket boom]. Available at: https://articles.t1.ua/styl/modni_trendy/26973-moda-lito-2019-fotopryntymikro-sumky-ta-kyshenkovyy-bum.html Статті T1.ua - твій портац (accessed 23 July 2021). (in Ukrainian).

24. Nikolajeva T. V., Shafransjka T. V., Nikolajeva T. I. (2019) Nacionaljni tradyciji jak osnova pidghotovky fakhivciv z dyzajnu odjaghu [National traditions as a basis for training experts in clothes design]. Art and Design, no. 1, pp. 140-149. DOI: 10.30857/2617-0272.2019.1.12 (in Ukrainian).

25. Persha bila suknja $v$ istoriji vesiljnoji mody [The first white dress in the history of wedding fashion]. Available at: https://burdastyle.ua/encyclopedia/ gid-po-stylyu/istoriya-kostyumu/persha-bila-suknya-v-istoriyi-vesilnoyimody (accessed 13 June 2021). (in Ukrainian).

26. Poltavsjkyj vesiljnyj rushnyk [Poltava wedding towel]. / Poltavsjkyj krajeznavchyj muzej im. V. Krychevsjkogho. Available at: http:// 
Tetiana Krotova, Kalyna Pashkevych. Dialogics of folk tradition and author's interpretation...

pkm.poltava.ua/ua/podii/1589-poltavskij-vesilnij-rushnik.html (accessed 29 July 2021). (in Ukrainian).

27. Pushkina V. (2003) Kozha [Leather] : prakt. rukov. : ucheb. rukov. Moskva : Eksmo. (in Russian).

28. Sovremennaya entsiklopediya. Moda i stil [Modern encyclopedia. Fashion \& Style] (2002). Moskva : Avanta+. (in Russian).

29. U stolyci Malajziji bulo prezentovano kolekciju dyzajnera Oksany Polonecj [The collection of designer Oksana Polonets was presented in the capital of Malaysia]. Available at: https://polonets.prom.ua/n266701-stolitsi-malajziyibulo.html (accessed 9 August 2021). (in Ukrainian).

30. Chuprina N. V., Kolosnichenko M. V. (2020) Eklektyzm jak osnova proektnykh praktyk u suchasnij systemi mody [Eclecticism as the basis of design practices in the modern fashion system]. Dyzajn odjaghu v polikuljturnomu prostori [Clothing design in a multicultural space] : monoghr. / M. V. Kolosnichenko, K. L. Pashkevych, T. F. Krotova ta in. Kyjiv : KNUTD, pp. 88-105. (in Ukrainian).

31. Shhucjka Gh., Patlashenko O., Bezsmertna T. Vykorystannja khudozhnjogho rozpysu ta novykh tekhnik dekoruvannja v kolekcijakh art ta fashion dyzajni odjaghu ta vzuttja [The use of artistic painting and new decorating techniques in the collections of art and fashion design of clothing and footwear]. Mizhnarodna naukovo-praktychna konferencija "Aktualjni problemy suchasnogho dyzajnu» [Current issues of modern design]. Pp. 426-429. Available at: https://er.knutd.edu.ua/bitstream/123456789/10599/1/ APSD2018_V1_P426-429.pdf (accessed 18 June 2021). (in Ukrainian).

32. Jak obraty vesiljni vyshyti sukni [How to choose embroidered wedding dresses]. Available at: https://sl-shop.com/yak-obrati-vesilni-vishiti-suknipo-vizerunkam.html (accessed 25 July 2021). (in Ukrainian).

33. Pashkevych K. L., Ovcharek V. Je. (2018) Osoblyvosti vykorystannja etnodzherel $\mathrm{v}$ dyzajni kolekcij suchasnogho odjaghu [Peculiarities of using ethno-sources in the design of modern clothing collections]. Teorija i praktyka dyzajnu, vol. 15, pp. 109-123. Available at: https://er.knutd.edu.ua/ handle/123456789/13312 (accessed 5 August 2021). (in Ukrainian).

34. Pashkevych K. L., Kryvonis N. A., Vyshnevska M. O., Rogotchenko O. O. (2019) Research of Ukrainian fashion industry goods consumers. Art and design, no. 1, pp. 9-21. DOI: 10.30857/2617-0272.2019.1.1 